\title{
Influência da suscetibilidade genética na incidência e mortalidade de COVID-19
}

\section{(SARS-CoV-2)}

\author{
Influence of genetic suscetibility on the incidence and mortality of COVID-19 (SARS-COV-2) \\ Influencia de la suscetibilidad genética sobre la incidencia y mortalidad del COVID-19 (SARS-
}

COV-2)

Steffany Larissa Galdino Galisa

ORCID: https://orcid.org/0000-0003-1761-2719

Universidade Estadual da Paraíba, Brasil

E-mail: steffany139@gmail.com

Raysla Maria de Sousa Almeida

ORCID: https://orcid.org/0000-0001-6192-5048

Universidade Estadual da Paraíba, Brasil

E-mail: almeida.rayslarms@gmail.com

Adriana Raquel Araújo Pereira Soares

ORCID: https://orcid.org/0000-0001-7815-4630

Universidade Estadual da Paraíba, Brasil

E-mail:dinha_raquel@hotmail.com

Radmila Raianni Alves Ribeiro

ORCID: https://orcid.org/0000-0002-8751-7437

Universidade Estadual da Paraíba, Brasil

Fábio Rodrigo Araújo Pereira

ORCID: https://orcid.org/0000-0003-0293-1776 Universidade Federal da Paraíba, Brasil

E-mail: fabiorodrigopereira@ hotmail.com

Kedma Anne Lima Gomes

ORCID: https://orcid.org/0000-0001-6720-011X UNIFACISA Centro Universitário, Brasil

E-mail: kalg2010@ hotmail.com

Milena Edite Casé de Oliveira

ORCID: https://orcid.org/0000-0003-2266-5890 Universidade Federal da Paraíba, Brasil E-mail: milacdo1@gmail.com

Waleska Fernanda Souto Nóbrega

ORCID: https://orcid.org/0000-0001-8140-4063

Universidade Estadual da Paraíba, Brasil

E-mail: drawaleskasouto@gmail.com

Lorena Sofia dos Santos Andrade

ORCID: https://orcid.org/0000-0003-4766-1482 E-mail: lorena_sofiacg@ hotmail.com

Tácila Thamires de Melo Santos ORCID: https://orcid.org/0000-0001-7487-0605 Centro Universitário Maurício de Nassau, Brasil E-mail: tacimelotj@hotmail.com

Beatriz Leodelgario Silva

ORCID: https://orcid.org/0000-0002-3477-4632 Centro Universitário Maurício de Nassau, Brasil E-mail: bia.silva5666@hotmail.com

\section{Resumo}

Este estudo teve como objetivo realizar uma revisão bibliográfica sobre a influência da suscetibilidade genética na incidência e mortalidade de COVID-19. Trata-se de uma revisão descritiva da literatura realizada nas bases de dados PUBMED e Science direct utilizando os seguintes descritores: genetic susceptibility" AND “COVID-19”. Os critérios de inclusão foram artigos científicos disponíveis gratuitamente, nos idiomas inglês, espanhol e português e que foram publicados em 2020. Foram excluídos os artigos duplicados entre as bases. Ao final 58 estudos seguiam os critérios estabelecidos. Os genes ACE2 e TMPRSS2, têm potencial para intervenção profilática e terapêutica nos estágios iniciais de infecção por SARS-CoV-2, desempenhando um papel crucial para a entrada do vírus nas células hospedeiras. Além disso, o lócus do Antígeno Leucocitário Humano (HLA), parece ser crucial para influenciar a suscetibilidade e a gravidade do COVID-19. Indivíduos do sexo masculino apresentam uma maior taxa de 
mortalidade e de gravidade para a COVID-19, sendo relacionado a uma expressão mais significativa de ACE2 e diferenças na regulação epigenética de $A C E 2$. A suscetibilidade genética pode contribuir para a variabilidade clínica interindividual associada ao COVID-19, permitindo uma avaliação de risco baseada em evidências levando a medidas preventivas personalizadas e opções terapêuticas.

Palavras-chave: Suscetibilidade genética; COVID-19; Síndrome respiratória aguda grave coronavírus 2 (Sars-cov-2).

\begin{abstract}
This study aimed to carry out a literature review on the influence of genetic susceptibility on the incidence and mortality of COVID-19. It is a descriptive review of the literature carried out in the PUBMED and Science direct databases using the following descriptors: genetic susceptibility "AND "COVID-19". The inclusion criteria were scientific articles available for free, in English, Spanish and Portuguese, which were published in 2020. Duplicate articles between databases were excluded. At the end, 58 studies followed the established criteria. The ACE2 and TMPRSS2 genes have the potential for prophylactic and therapeutic intervention in the early stages of SARS-CoV-2 infection, playing a crucial role in the entry of the virus into host cells. In addition, the locus of Human Leukocyte Antigen (HLA) appears to be crucial to influence the susceptibility and severity of COVID-19. Male individuals have a higher mortality and severity rate for COVID-19, being related to a more significant expression of ACE2 and differences in the epigenetic regulation of ACE2. Genetic susceptibility can contribute to the interindividual clinical variability associated with COVID-19, allowing for an evidence-based risk assessment leading to personalized preventive measures and therapeutic options.
\end{abstract}

Keywords: Genetic susceptibility; COVID-19; Severe acute respiratory syndrome coronavirus 2 (Sars-cov-2).

\title{
Resumen
}

Este estudio tuvo como objetivo realizar una revisión de la literatura sobre la influencia de la susceptibilidad genética en la incidencia y mortalidad de COVID-19. Se trata de una revisión descriptiva de la literatura realizada en las bases de datos PUBMED y Science direct utilizando los siguientes descriptores: susceptibilidad genética "Y" COVID-19". Los criterios de inclusión fueron artículos científicos disponibles de forma gratuita, en inglés, español y portugués, que fueron publicados en 2020. Se excluyeron artículos duplicados entre bases de datos. Al final, 58 estudios siguieron los criterios establecidos. Los genes ACE2 y TMPRSS2 tienen el potencial de una intervención profiláctica y terapéutica en las primeras etapas de la infección por SARS-CoV-2, desempeñando un papel crucial en la entrada del virus en las células huésped. Además, el locus del antígeno leucocitario humano (HLA) parece ser crucial para influir en la susceptibilidad y la gravedad de COVID-19. Los varones tienen una mayor tasa de mortalidad y gravedad para COVID-19, lo que se relaciona con una expresión más significativa de ACE2 y diferencias en la regulación epigenética de ACE2. La susceptibilidad genética puede contribuir a la variabilidad clínica interindividual asociada con COVID-19, lo que permite una evaluación del riesgo basada en la evidencia que conduce a medidas preventivas personalizadas y opciones terapêuticas.

Palabras clave: Predisposicion genética; COVID-19; Síndrome respiratorio agudo severo coronavirus 2 (Sars-cov-2).

\section{Introdução}

A síndrome respiratória aguda grave coronavírus 2 (SARS-CoV-2), surgiu na população chinesa em dezembro de 2019, causando a pandemia global de COVID-19 (Devaux, Rolain \& Raoult, 2020). Em consequência disso, comprometeu drasticamente o sistema de saúde pública em vários países (Li et al., 2020; Thomson 2020; Liu et al., 2020). Até o mês de agosto de 2020, foram confirmados quase 20 milhões de casos mundialmente, totalizando mais de 719.000 mortes acometidas por essa doença (Li et al., 2020; Elhabyan et al., 2020). Sendo assim, o acompanhamento das mudanças epidemiológicas da COVID-19 no Brasil e no mundo apontam que a doença ainda não está sob controle. Como o vírus (SARS-COV-2) é altamente transmissível, podendo uma pessoa infectada transmitir de duas a quatro pessoas, é de fundamental importância manter as medidas de prevenção como o distanciamento social e o uso de máscaras, sendo melhor forma de evitar a progressão de casos e mortes por COVID-19 (Sousa et al., 2020; De figueiredo et al., 2020).

Segundo Chen e Zheng (2020), os indivíduos acometidos pela COVID-19 podem apresentar desde sintomas respiratórios, gastrointestinais e até neurológicos. Além disso, há variação no quadro clínico dos pacientes infectados por essa doença que pode variar de um quadro assintomático a quadros de infecções mais graves. Existe ainda uma taxa de mortalidade notavelmente alta entre os idosos e as pessoas que possuem doenças crônicas (Mitra et al., 2020). 
Devido a enorme evolução, adaptação e disseminação do SARS-CoV-2, cientistas de todo o mundo investigam os aspectos de sua replicação e patogênese, no intuito de encontrar alvos terapêuticos mais eficazes (Zuil et al., 2020). Recentemente foram observadas semelhanças na suscetibilidade de COVID-19 entre indivíduos geneticamente relacionados sugerindo uma seletividade do vírus SARS-CoV-2 que depende da afinidade por perfis genéticos selecionados. A seletividade determina a suscetibilidade da doença clínica e a extensão da patogênese (Khan, 2020). Lacoma et al., 2019, afirmam que os fatores genéticos somados a outros fatores de risco, são determinantes para a suscetibilidade de desenvolver infecções do trato respiratório.

Dessa forma, é de fundamental importância compreender as causas das variações genéticas entre os indivíduos relacionado à sua suscetibilidade intrínseca de ser infectado, além de entender o avanço da doença e os mecanismos de resposta do sistema imunológico à infecção pelo SARS-CoV-2 (Chen \& Zheng, 2020). Diante disso, o objetivo do presente trabalho foi realizar uma revisão bibliográfica sobre a influência da suscetibilidade genética na incidência e mortalidade de COVID-19.

\section{Metodologia}

Foi realizada uma revisão narrativa da literatura de natureza qualitativa, uma vez que busca explorar, descrever e discutir sobre o tema proposto (Pereira et al., 2018). A busca foi realizada entre dezembro de 2020 e janeiro de 2021 . As bases eletrônicas pesquisadas foram PubMed e Science Direct, utilizando os seguintes descritores: "genetic susceptibility” AND “COVID-19”. Os critérios de inclusão foram: publicações em 2020, artigos completos disponíveis gratuitamente e nos idiomas inglês, espanhol e português. Enquanto os critérios de exclusão foram artigos duplicados entre as bases e que não se enquadraram nos critérios de interesse da ideia central dessa revisão. Foram encontrados 938 trabalhos ao todo, sendo 194 disponíveis na PubMed e 744 no Science Direct. Contudo, apenas 58 estudos seguiam os critérios estabelecidos na metodologia (Figura 1).

Figura 1. Representa de forma esquemática a realização da busca de artigos nas duas bases de dados utilizadas na construção do presente trabalho.

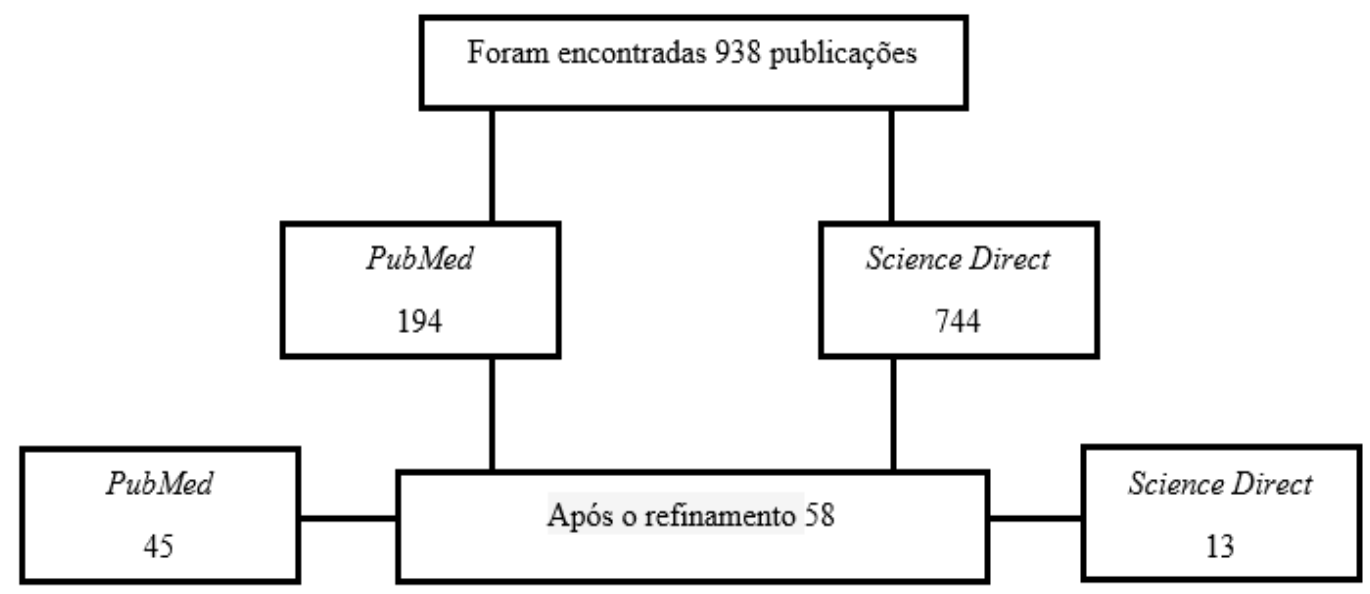

Fonte: Autores. 


\section{Resultados}

A COVID-19 causada pela Síndrome Respiratória Aguda Grave Coronavírus 2 (SARS-CoV-2) é considerada um problema de saúde pública mundial (Latini, et al., 2020; Panda, Padhi \& Prusty, 2020). Fatores como a alta taxa de transmissão, variações na taxa de mortalidade em várias regiões do planeta e variações no quadro clínico dos indivíduos infectados são uma das características marcantes dessa patologia (Debnath, Banerjee \& Berk, 2020; Vargas-Alarcón, PosadasSánchez \& Ramírez-Bello, 2020). Ademais, há também diferença na resposta às drogas antivirais entre as diferentes populações (Paniri et al., 2020), idade, sexo e na presença de comorbidades (Pereira et al., 2020).

Essas características associadas à presença de vários subtipos do coronavírus podem ser explicadas por meio das diferenças genéticas nas populações (Vargas-Alarcón, Posadas-Sánchez \& Ramírez-Bello, 2020). Um exemplo é o grupo étnico afro-americano que apresenta um maior risco de serem acometidos pela COVID-19 e os indivíduos do sexo masculino que apresentam uma taxa numérica e de gravidade elevada quando comparados com as mulheres (Abdelzaher et al., 2020). Dito isto, acredita-se que determinados grupos estão mais suscetíveis geneticamente a serem infectados e/ou mais expostos a gravidade dessa doença (Abdelzaher et al., 2020; Benetti et al., 2020; LoPresti et al., 2020) devido às diferenças na patogenicidade de um indivíduo infectado pelo SARS-CoV-2 em relação ao outro (Chakravarty et al., 2020).

Desse modo, por se tratar de uma doença com uma suscetibilidade e gravidade altamente heterogênea (Pereira et al., 2020) é indiscutível a importância de estudos relacionados tanto com os fatores de riscos genéticos para a suscetibilidade quanto aos diferentes polimorfismos genéticos existentes em diferentes populações (Alshahawey, Raslan \& Sabri, 2020) e aos fatores genéticos do hospedeiro (Choudhary et al., 2020; Debnath, Banerjee \& Berk, 2020; Murray et al., 2020). Além dos mecanismos potenciais como a predisposição genética a doenças (Godri Pollitt et al., 2020; Murray et al., 2020; Zhu et al., 2020), expressão de genes que podem atuar como facilitadores da entrada do SARS-CoV-2 nos indivíduos, do processo de replicação, da resposta imunológica (Chakravarty et al., 2020; Debnath, Banerjee \& Berk, 2020) e até mesmo da resistência do hospedeiro a essa doença (Godri Pollitt et al., 2020; Gutierrez, Beckford \& Alachkar, 2020; Mohammadpour et al., 2020; Murray et al., 2020).

Portanto, compreender esses mecanismos pode contribuir de maneira significativa para o combate dessa doença em vários âmbitos, como por exemplo, no desenvolvimento de medidas terapêuticas (Carter-Timofte et al., 2020; Wei et al., 2020), preventivas (Carter-Timofte et al., 2020) e profilaxias mais específicas de acordo com o quadro clínico dos pacientes (Carter-Timofte et al., 2020; Wei et al., 2020). Ademais, também contribui para uma identificação mais precisa em relação aos genes protetores e aos indivíduos que são considerados grupo de risco para a suscetibilidade do COVID-19 devido à presença de genes de riscos (Debnath, Banerjee \& Berk, 2020). Contudo, apesar da importância dessa área ainda há poucos estudos publicados em relação a essa temática (COVID-19 Host Genetics Initiative, 2020).

\subsection{Genes associados à suscetibilidade de COVID-19}

Embora poucos estudos de fatores genéticos em grande escala, como os estudos de associação do genoma (GWAS), foram publicados na literatura sobre o SARS-CoV-2, as primeiras evidências implicam na influência dos genes $A C E$, $A C E 2$ e TMPRSS2 (Pereira et al., 2020). Recentemente, verificou-se que tanto a Enzima de Conversão da Angiotensina 2 (ACE2) quanto a Protease Serina Transmembrana tipo 2 (TMPRSS2), estão desempenhando um papel crucial para a entrada do vírus nas células hospedeiras, onde, ACE2 é considerado o principal receptor para o pico da proteína (S), através do qual o vírus pode se ligar às células-alvo. Enquanto o gene TMPRSS2 cliva a proteína (S), permitindo a fusão adicional do vírus e da membrana celular (Alshahawey, Raslan \& Sabri, 2020). O SARS-CoV-2 tem uma forte interação com o receptor ACE2 
humano, que desempenha um papel essencial na entrada da célula juntamente com a serina protease 2 transmembrana (TMPRSS2) (Gemmati, 2020).

As tendências atuais mostram que alelos de polimorfismos de nucleotídeo único (SNPs) do gene ACE2 e variantes genéticas de TMPRSS2, podem determinar um espectro multifatorial complexo de virulência de SARS-CoV2 entre pacientes e prever a suscetibilidade a COVID-19 (Chiappelli, 2020). A protease transmembrana serina 2 (TMPRSS2) e as proteases cisteínicas endossômicas catepsina B e L (CatB / L) ativam a proteína spike de SARS-CoV-2 permitindo que o vírus se ligue ao receptor $A C E 2$ na superfície celular e, posteriormente, entre na célula por endocitose. Além disso, o gene $A C E$ que codifica a enzima ACE1 é caracterizado por uma deleção / inserção (D / I), polimorfismo no íntron 16, sendo o alelo D associado à diminuição da expressão do receptor ACE2. Portanto, os estudos têm se concentrado em determinar se as variantes genéticas em ACE, ACE2 e TMPRSS2, assim como em outros genes, impactam a infecção por COVID-19 (Pereira et al., 2020).

Variações genéticas e epigenéticas nos genes ACE2, TMPRSS2 e FURIN, como componentes centrais para a entrada da célula SARS-CoV-2, e também em outras moléculas que modulam sua expressão como os genes CALM, ADAM-17, AR e ESRs pode discriminar potencialmente indivíduos que apresentam risco aumentado de infecção por SARS-CoV-2 ou são potencialmente resistentes. Foram identificados vários polimorfismos que podem afetar a atividade das enzimas acima (Ragia \& Manolopoulos, 2020). Alguns genes cruciais foram também associados a COVID-19: RPA2, POLD4, MAPK8, IRF7, JUN, NFKB1, NFKBIA, CD4 OLG, FASLG, ICAM1, LIFR, STAT2 e CCR1. A maioria desses genes está relacionada ao sistema imunológico e aos órgãos respiratórios, o que enfatiza o fato de que a doença pulmonar obstrutiva crônica enfraquece esse sistema e torna os pacientes mais suscetíveis a desenvolver COVID-19 grave (Sharma, Pandey \& Bhattacharyya, 2020). Além disso, a maioria das variações de nucleotídeo único em ACE2 e TMPRSS2 são raros, específicos para a população e deletérios, podendo explicar a suscetibilidade diferente ao SARS-CoV-2 (Fujikura et al., 2020).

\subsection{Genes $A C E 1$ e $A C E 2$}

O sistema da angiotensina está implicado na patogênese da COVID-19. O equilíbrio entre a atividade da ACEI e da ACE2 tem sido implicado na patogênese das doenças respiratórias e têm um papel importante na gravidade da COVID-19. Polimorfismos funcionais dos genes ACE1/ACE2 têm sido associados ao risco de doenças cardiovasculares e pulmonares e, portanto, também podem contribuir para o desfecho de COVID-19 (Gómez et al., 2020).

A enzima conversora de angiotensina 2 (ACE-2), é um homólogo de ACE descoberto em 2000. O gene ACE2 é encontrado no cromossomo Xp22 e compreende 18 exons. Este atua como um receptor funcional para a síndrome respiratória aguda grave do coronavírus 2 (SARS-CoV-2) (Choudhary et al., 2020; Moradi, Enjezab \& Ghadiri-Anari, 2020). O SARSCoV-2 entra nas células pela interação entre a proteína spike do SARS-CoV-2 e a molécula receptora da enzima conversora da angiotensina 2 (ACE2) expressa na superfície das células alvo, de modo que os polimorfismos e o nível de expressão de ACE2 influenciam a suscetibilidade e consequente patogênese do SARS-CoV-2 (Phillips et al., 2020). Essa interação dificulta a ação protetora da ACE2 nas células e causa lesões aos órgãos devido ao nível persistente de angiotensina II (Ang-II). Por isso, pacientes com certas comorbidades como hipertensão, diabetes e doenças cardiovasculares estão sob alto risco de infecção e mortalidade por COVID-19 (Agrawal et al., 2020).

O gene ACE2 tem múltiplas funções, incluindo atividades catalíticas com substratos específicos; atua como um regulador negativo do sistema renina-aldosterona, transportador de aminoácidos B0 AT1 e receptor para coronavírus (SARSCoV). ACE2 restringe os efeitos adversos da Ang II em profibróticos e vasoconstritores. A hidrólise da Ang II em Ang 1-7 diminui o estresse oxidativo, e a Ang 1-7 tem mecanismos contra-reguladores, incluindo ações antifibróticas e vasodilatadoras. Consequentemente, o distúrbio de ACE2 leva a níveis elevados de Ang II e redução da função cardíaca. ACE2 é ativo em vários tecidos e está disseminado nos pulmões, rins, coração e testículos. Baixos níveis de expressão de mRNA de ACE2 foram 
associados a hipertensão e insuficiência cardíaca e níveis reduzidos de ACE2 cardíaco foram relatados em hipertensão e doença cardíaca diabética. Essas múltiplas funções fisiológicas da ACE2 foram sequestradas pelo SARS-CoV-2 para servir como um receptor, resultando na COVID-19 (Choudhary et al., 2020).

Variações no gene $A C E 2$ alterando a estrutura do receptor ou o nível de expressão podem tornar mais fácil ou mais difícil para o SARS-CoV-2 invadir as células (Zhang et al., 2020). Por isso os níveis de expressão de ACE2 celular diferem entre os indivíduos (Choudhary et al., 2020). Em um estudo realizado foi visto que a expressão global de ACE2 foi significativamente maior em pacientes com diabetes, hipertensão e doença pulmonar obstrutiva crônica do que nos pulmões de pacientes saudáveis (Pinto et al., 2020). Isso pode explicar por que esses indivíduos estão predispostos a uma maior gravidade da COVID - 19; no entanto, outros estudos sugerem que a expressão de ACE2 mais alta pode ser protetora contra lesão pulmonar, e a expressão de $A C E 2$ diminui com a idade (pelo menos em um modelo animal) (Pathak et al., 2020).

Estudos adicionais são necessários para determinar se a modulação de ACE2 é um resultado direto de comorbidades subjacentes ou se a expressão aumentada ou diminuída de ACE2 nesses indivíduos em certas localizações é causal para COVID - 19 grave (Ovsyannikova et al., 2020) Além disso, compreender os genes que interagem com o receptor ACE2 tem potencial para compreender alvos de drogas e processos moleculares que podem desempenhar um papel na suscetibilidade e resposta ao tratamento de COVID-19 (Pathak et al., 2020).

Uma tendência diferente de expressão de ACE2 foi observada em crianças. Em geral, as crianças com COVID-19 confirmado são levemente sintomáticas ou principalmente assintomáticas. As crianças geralmente têm níveis plasmáticos de ACE2 mais elevados do que os adultos. Por exemplo, os níveis plasmáticos de ACE2 em crianças (seis meses a 17 anos de idade) foram de 13-100 U/L em comparação com 9-67 U/L na população adulta. Em um estudo incluindo 1.099 pacientes na China, apenas 0,9\% dos casos confirmados tinham menos de nove anos de idade e apenas $1,2 \%$ tinham de 10 a 19 anos. A correlação entre a gravidade do COVID-19 e a idade pode ser explicada com base no declínio imunológico, bem como em um perfil ACE2 plasmático incomum específico para crianças (Choudhary et al., 2020).

\subsubsection{Variantes genéticas de $A C E 1$ e $A C E 2$}

Uma comparação de dados de sequenciamento completo do exoma de 131 casos de COVID-19 e 258 controles na Itália, demonstraram uma prevalência maior de variantes do ACE2 que prejudicam a expressão ou função do receptor $A C E 2$ na coorte de controle, sugerindo que essas variantes são protetoras contra SARS-CoV-2. As análises in sílico sugerem que algumas variantes desse gene podem enfraquecer ou fortalecer a ligação da proteína spike SARS-CoV-2 à proteína ACE2, respectivamente, diminuindo ou aumentando a susceptibilidade à infecção (Pereira $e t$ al., 2020). Foi previsto que dois SNPs missense rs149039346 e rs147311723 influenciam fortemente a função e a estabilidade do ACE2. Existem papéis fundamentais dos SNPs em ACE2 para sua interação com COVID-19 e, consequentemente, a suscetibilidade ao vírus. Portanto, as diferentes respostas dos pacientes com COVID-19 aos bloqueadores da ACE2 podem ser devidas aos seus SNPs exclusivos (Paniri et al., 2020).

A deleção $(D)$ ou inserção $(I)$ de uma sequência de repetição Alu de 287 pb no íntron 16 é um polimorfismo importante encontrado no gene ACE1. O genótipo $D D$ mostrou duas vezes a atividade em comparação com o genótipo II. Além disso, os pacientes com o genótipo II têm uma chance significativamente maior de sobrevivência do que os pacientes com outros genótipos. A prevalência do genótipo $D D$ é maior em pacientes com infecções pulmonares graves e está significativamente correlacionada com uma alta taxa de mortalidade (Al-Eitan \& Alahmad, 2020).

A frequência do genótipo II da $A C E 1$ em uma população foi significativamente correlacionada negativamente com o número de casos de SARS-CoV-2. A infecção viral, diminuiu com o aumento da frequência do genótipo II. Isso sugere que o genótipo I/D pode estar envolvido em várias condições patológicas causadas pela infecção por SARS-CoV-2, como 
pneumonia, coagulação intravascular disseminada e trombose, acidente vascular cerebral isquêmico, lesão renal e resposta imune, como tempestade de citocinas. Esses dados sugerem que o genótipo II pode influenciar a prevalência e o resultado clínico de COVID-19 e servir como um marcador preditivo para o risco e a gravidade do COVID-19 (Yamamoto et al., 2020).

Existe uma diferença racial bem estabelecida do polimorfismo do gene ACE. Nos Estados Unidos, os afro-americanos são conhecidos por terem a maior frequência do alelo $D$ (89\%) quando comparados aos indianos (69\%) e aos brancos $(69 \%)$. Na Europa, as populações da Itália, Espanha e França apresentam alta frequência do alelo $D$ de até $82 \%$ a $87 \%$. Em contraste, na Ásia, as populações da Ásia Oriental, como chinesa, coreana, taiwanesa e japonesa, têm uma alta frequência do alelo do gene II da ACE, que é supostamente maior do que as populações europeias (33\% a 51\% contra $13 \%$ a 27\%). Populações com alta frequência de alelos $D$ parecem ter maior letalidade. Por exemplo, os afro-americanos parecem ter uma taxa de mortalidade desproporcionalmente alta dos Estados Unidos. Da mesma forma, pacientes da Itália, Espanha e França também apresentam alta letalidade na Europa. Por outro lado, a baixa frequência do genótipo $D / D$ de $A C E$ e a alta frequência do genótipo II observadas em populações asiáticas parece estar associada a uma mortalidade relativamente baixa de COVID-19 nessas nações (Zheng \& Cao, 2020).

Estudos subsequentes mostraram uma diferença marcante na frequência de alelos entre europeus e asiáticos para um polimorfismo rs2285666, presente em ACE2. Foi revelado que o alelo alternativo (fita TT-plus ou fita AA-menos) de rs2285666 eleva o nível de expressão desse gene em até 50\%, portanto, pode desempenhar um papel significativo na suscetibilidade ao SARS-CoV-2. Foi verificada também uma correlação positiva significativa para o alelo alternativo (T ou A) de rs2285666, com a menor taxa de infecção e letalidade entre as populações indianas (Al-Eitan \& Alahmad, 2020).

As populações do leste asiático têm maiores frequências de alelos de variantes de eQTL associadas à maior expressão de ACE2, possivelmente levando ao aumento susceptibilidade à infecção (Pereira et al., 2020). Na população africana os polimorfismos da ACE2 estão associados a condições cardiovasculares e pulmonares por meio da alteração das interações angiotensinogênio-ACE2, como p.Arg514Gly (Hou et al., 2020)

Três variantes missense mais frequentes, p. (Asn720Asp), p. (Lys26Arg) e p. (Gly211Arg) apresentaram um impacto potencial na estabilidade da proteína ACE2. Foram observadas também que as variantes raras p. (Leu351Val) e p. (Pro389His) provavelmente interferem na ligação da proteína spike SARS-CoV-2, influenciando o processo de internalização (Benetti et al., 2020). Além disso, as variantes genéticas rs73635825 (S19P) e rs143936283 (E329G) em ACE2 mostraram variações perceptíveis em suas interações intermoleculares com a proteína do pico viral. Esses dados fornecem uma base estrutural de resistência potencial contra a infecção por SARS-CoV-2 impulsionada por variantes alélicas de ACE2 (Hussain et al., 2020).

Em outro estudo observou-se que diferentes resíduos de aminoácidos expressos no receptor ACE2 são muito relevantes, tanto por promover quanto por prevenir a infecção viral. Um total de 13 polimorfismos (rs1434130600, rs1395878099, rs142984500, rs756231991, rs1244687367, rs73635825, rs778500138, rs867318181, rs763395248, rs4646116, rs778030746, rs1199100713 e rs781255386) parecem contribuir no reconhecimento de ACE2 / S1, facilitando desse modo a infecção de SARS-CoV-2. Em contraste, 18 SNPs (rs143936283, rs961360700, rs1569243690, rs751572714, rs1348114695, rs1263424292, rs766996587, rs760159085, rs1016409802, rs146676783, rs1352194082, rs755691167, rs1325542104, rs759579097, rs762890235, rs1192192618, rs370610075 e rs1256007252) parecem impedir as interações entre ACE2 e S1, reduzindo assim a taxa de infecção (Al-Eitan \& Alahmad, 2020).

Três SNPs E329G (rs143936283), M82I (rs267606406) e K26R (rs4646116), tiveram uma redução significativa na energia livre de ligação, o que indicou maior afinidade de ligação do que ACE2 do tipo selvagem e maior suscetibilidade à infecção por SARS-CoV-2. Três outros SNPs, D355N (rs961360700), E37K (rs146676783) e I21T (rs1244687367), tiveram um aumento significativo na energia livre de ligação, o que indicou menor afinidade de ligação e susceptibilidade reduzida à infecção SARS-CoV-2 (Wang et al., 2020). 


\subsection{Gene TMPRSS2}

O gene TMPRSS2 está intimamente associado com o aumento da taxa de mortalidade a COVID-19 nos indivíduos do sexo masculino (Abdelzaher et al., 2020). Esse gene é responsável pela codificação da protease transmembrana em seres humanos, podendo ser expresso em várias regiões do corpo, sendo as principais nos pulmões, nos enterócitos absortivos e nas células endoteliais superiores do esôfago. Uma das principais características dessa enzima é a presença tanto de um domínio transmembrana do tipo 2 quanto de um domínio de receptores de classe A. De acordo com a literatura, essas proteases são fundamentais para o desenvolvimento de vários processos no corpo humano, sejam eles de caráter patológico, homeostático ou até mesmo fisiológico (Choudhary et al., 2020).

Segundo estudos publicados recentemente, esse gene está relacionado com a entrada do vírus do COVID-19 nas células hospedeiras por possibilitar a clivagem do receptor SARS-CoV-2 e a ativação dessa proteína durante a etapa de fusão da membrana (Choudhary et al., 2020). Essa facilitação ocorre devido a presença de andrógenos que apresentam como função regular a expressão do TMPRSS2 (Pereira et al., 2020). Portanto, os baixos níveis de andrógenos em mulheres atuam como um fator de proteção contra o desenvolvimento dessa patologia por contribuírem para uma diminuição na expressão desse gene (Foresta, Rocca \& Di Nisio, 2020). Devido a isso, tem sido desenvolvido estudos direcionados para a criação de um tratamento que visa a inativação e/ou diminuição desse regulador em indivíduos do sexo masculino que foram infectados por essa patologia (Pereira et al., 2020). Estudos utilizando o gene ACE2 também apresentaram resultados semelhantes para esse mecanismo de ativação, visto que ambos os genes contribuem de maneira significativa para o aumento da entrada viral nos indivíduos (Barash et al., 2020; Choudhary et al., 2020; Latini, et al., 2020).

\subsubsection{Variantes genéticas do gene TMPRSS2}

Variantes genéticas do gene TMPRSS2 foram postuladas como responsáveis pelos dados epidemiológicos do SARSCoV-2 (Choudhary et al., 2020). A frequência dos alelos de variantes genéticas no gene TMPRSS2 também difere entre as populações. Por exemplo, as populações do Leste Asiático têm uma frequência mais baixa de genótipos de alta expressão em comparação com as populações americanas e europeias que exibem uma frequência mais alta de genótipos de baixa expressão. Além disso, quatro SNPs regulatórios encontrados no gene TMPRSS2 (rs77675406, rs112657409, rs713400 e rs11910678) desempenham um papel importante na regulação da expressão dos principais genes regulatórios que estão envolvidos no processo de infecção do SARS-CoV-2 (Al-Eitan \& Alahmad, 2020). Foi relatado também que o SNP p.Val160Met (rs12329760) localizado no gene TMPRSS2 contribui não só para a suscetibilidade genética de COVID-19, mas também como fator de risco para essa doença (Hou et al., 2020).

Em outro estudo foi observado diferenças de frequência alélica da variante rs12329760 e haplótipos eQTL em populações da Itália e do Leste Asiático (Choudhary et al., 2020). Na população italiana, as taxas de mortalidade e a variação na gravidade do COVID-19 foram significativamente maiores do que na população do Leste Asiático. A população italiana demonstrou uma diminuição notável na carga de variantes prejudiciais da protease TMPRSS2 em comparação com outros europeus. Desse modo supõe-se que o gene TMPRSS2 desempenha um papel importante na gravidade da doença. Em comparação com os asiáticos do leste, a população italiana teve um aumento de $9 \%$ nesta frequência de alelo menor. Além disso, três SNVs, rs2070788, rs9974589 e rs7364083, que compreendem um haplótipo, foram associados a maior expressão de TMPRSS2 (Choudhary et al., 2020).

Irham et al., (2020), relataram que o gene TMPRSS2 é altamente expresso no sistema respiratório humano. Os SNPs rs383510 e rs464397 deste gene mostraram a maior expressão no pulmão com genótipos homozigotos TT. O genótipo heterozigoto CT mostrou um nível intermediário de expressão, enquanto o genótipo homozigoto CC teve a expressão mais baixa. Além disso, o genótipo GG do SNP rs2070788 apresentou maior expressão no pulmão, enquanto os genótipos AG e AA 
apresentaram níveis mais baixos de expressão. O SNP rs469390 também mostrou um alto nível de expressão com o genótipo AA, enquanto o genótipo AG tem um nível de expressão intermediário e o genótipo GG tem o nível de expressão mais baixo. Juntos, os genótipos com altos níveis de expressão no pulmão podem estar correlacionados com maior suscetibilidade à infecção por SARS-CoV-2 (Al-Eitan \& Alahmad, 2020).

\subsection{Sistema antígeno leucocitário humano (HLA)}

O lócus do Antígeno Leucocitário Humano, um regulador mestre da imunidade contra a infecção, parece ser crucial para influenciar a suscetibilidade e a gravidade do COVID-19 (Debnath, Banerjee \& Berk, 2020). O antígeno leucocitário humano (HLA) é um dos sistemas de antígenos mais polimórficos (Mohammadpour et al., 2020). Existe uma associação entre os polimorfismos genéticos HLA e a suscetibilidade e mortalidade de pacientes com doença coronavírus, como por exemplo, o alelo $H L A-A * 11$ que está associado a maior mortalidade da doença (Lorente et al., 2020). Atualmente há relatos limitados na literatura de estudos que investigam a variação genética do HLA e a resposta imune contra SARS-CoV-2. Embora os dados biológicos sejam limitados, vários estudos relataram o uso de algoritmos preditivos para identificar alelos HLA associados ao reconhecimento de epítopos de peptídeos virais. Esses estudos podem fornecer algumas evidências de quais alelos HLA desempenham papéis importantes na mediação da proteção contra SARS-CoV-2 (Ovsyannikova $e t$ al., 2020).

As diferenças genéticas nos genes HLA são bem conhecidas por influenciar as variações individuais na resposta imune aos patógenos. Essas diferenças genéticas nos genes influenciam o reconhecimento de células $\mathrm{T}$ de antígenos derivados de patógenos. Uma análise in silico da afinidade de ligação do peptídeo viral - MHC classe I em mais de 100 genótipos HLA$A$, -B e -C para todos os peptídeos SARS-CoV-2 mostrou que o alelo HLA-B * 46: 01 tinha o menor número de peptídeos de ligação previstos para SARS-CoV-2, sugerindo maior vulnerabilidade ao COVID-19 entre indivíduos com este alelo podendo apresentar uma resposta imunológica mais fraca e desenvolvendo sintomas mais graves. Em contrapartida, HLA-B*15: 03 demonstrou ter a maior capacidade de apresentar peptídeos SARS-CoV-2 altamente conservados que são compartilhados entre coronavírus humanos, sugerindo que pacientes que possuem este genótipo podem ter maior probabilidade de desenvolver imunidade (Gutierrez, Beckford \& Alachkar, 2020; Godri Pollitt et al., 2020; Ovsyannikova et al., 2020).

Em outro estudo realizado com um grupo de 99 pacientes italianos afetados por uma forma grave ou extremamente grave de COVID-19 foi observado uma associação significativa para $H L A-D R B 1 * 15$ : 01, -DQB1 * 06: 02 e -B * 27: 07, após comparar os resultados a um grupo de referência de 1017 italianos. As frequências aumentadas dos marcadores podem contribuir para identificar potenciais marcadores de suscetibilidade à doença (Novelli et al., 2020). Outra pesquisa mostrou que os genes $H L A-C \mathrm{w} * 1502$ e DRB1 * 0301 podem ser os fatores de resistência da infecção por SARS-CoV-2. O HLA-B * 0703, por outro lado, apresentou um aumento significativo no grupo de pacientes com SARS-CoV-2 (Mohammadpour et al., 2020). Essas observações levantam a importante questão de quais alelos conferem suscetibilidade ou resistência à infecção por SARSCoV-2 (Gutierrez, Beckford \& Alachkar, 2020).

Em uma análise de 12.343 sequências do genoma do SARS-CoV-2 isoladas de pacientes em seis áreas geográficas, foram identificadas um total de 1234 mutações comparando-as com a sequência de referência do SARS-CoV-2. Ao final as variantes do ORFlab 4715L e da proteína S 614G, mostraram correlações positivas significativas com as taxas de fatalidade. Além disso, foi descoberto que o estado de vacinação com BCG está significativamente associado às taxas de mortalidade, bem como ao número de casos infectados. Em países vacinados com BCG, a frequência das variantes S 614G e HLA-A * 11: 01, teve uma tendência de associação com a maior taxa de letalidade. A partir disso, supõe-se que os genótipos HLA bem como o estado de vacinação com BCG podem afetar a suscetibilidade à infecção pelo SARS-CoV-2 ou a gravidade do COVID-19 (Toyoshima et al., 2020). 
No estudo de Pisanti et al., 2020, foi descoberto que dois haplótipos HLA frequentes na população italiana, $H L A-A *$ : 01: 01g-B * 08: $01 \mathrm{gC} *$ 07: 01g-DRB1*03: 01g e HLA-A *02.01 gB * 18,01gC * 07,01g-DRB1*11,04g, tiveram uma distribuição regional sobreposta à de Covid-19 e mostrou, respectivamente, uma correlação significativa positiva (sugestiva de suscetibilidade) e negativa (sugestiva de proteção) com incidência e mortalidade de Covid-19 (Pisanti et al., 2020). Foi identificado também que os alelos $H L A-A * 11: 01, \mathrm{~B} * 51: 01$ e $\mathrm{C} * 14: 02$ predispõem significativamente ao pior desfecho dos pacientes (Wang et al., 2020).

Em outro estudo foi observado que um aumento de $1 \%$ na frequência do alelo do $H L A-C * 05$ foi associado a um aumento de 44 mortes/milhão. Países com mortalidade diferente podem ser categorizados pela distribuição de $H L A-C * 05$ e seu receptor KIR2DS4fl, que em combinação causam resposta imune hiperativa induzida por células NK. Foi demostrado que a frequência alélica do $H L A-C * 05$ e o padrão de distribuição com seu receptor KIR2DS4fl se correlacionaram fortemente com a mortalidade do COVID-19 (Sarakuba, Haider \& Sato, 2020).

Respostas imunes diferenciais foram observadas também em casos leves e graves de COVID-19, incluindo respostas IgM atrasadas e títulos de IgG de proteína S mais elevados em pacientes não - UTI, levantando as questões de como a variação alélica do HLA contribui para essa imunidade diferencial. É fundamental determinar e comparar os perfis de HLA entre os indivíduos com casos graves de COVID-19 com aqueles que têm doença leve. Isso ajudará na compreensão dos mecanismos subjacentes da imunidade protetora inata e adaptativa e pode levar ao desenvolvimento de marcadores genéticos como correlatos de proteção (Ovsyannikova et al., 2020).

\subsection{Outros genes associados}

Existem outros genes que também parecem ser associados à suscetibilidade ao SARS-CoV-2. De acordo com uma revisão sistemática foi identificado 29 polimorfismos localizados em 21 genes como associados à suscetibilidade ou resistência ao SARS-CoV-2 e gravidade da doença em populações asiáticas. São eles, o já conhecido ACE1 - Inserção / exclusão (I / D); CD209- -336A> G; CLEC4M - Domínio de repetição em tandem no exon 4; ICAM-3 - Asp143Gly; IFN- $\gamma$ - +874 A / T; ranta - -28C / G; OAS-1-SNP A / G no exon 3; SNP A / G no locus 3'UTR 347 do exon 8; Mxa - -123C> A; SNP G / T na posição -88 na região promotora, SNP G / T na posição -88 na região promotora; IL-12 RBI - +1664 C / T; FcgRIIa - H131R; $M L B$ Variante do códon 54 (A / B); CCL2 - G-2518a; AHSG - -799A / T; TNF- $\alpha$ - -204, -308G / A; CD14 - -159C / T; HLA-B $\mathrm{B} * 0703, \mathrm{~B} * 4601, \mathrm{~B} * 1502 ; H L A-D R B 1$ - $\mathrm{DRB} 1 * 0301, \mathrm{DRB} 1 * 1202 ;$ HLA-DRB4 - DRB4*01010101; HLA-DRB3 DRB3*030101; HLA-Cw - Cw*0801, Cw*1502; HLA-DR - DR*0301 (Ramos-Lopez et al., 2020).

No estudo realizado por Dobrindt et al., 2020, foi identificado que o polimorfismo de nucleotídeo único (rs4702) afeta a infecção alveolar e neuronal por SARS-CoV-2 in vitro. Com isso, supõe-se que a variação genética comum pode impactar a infecção viral e, assim, contribuir para a heterogeneidade clínica no SARS-CoV-2 (Dobrindt et al., 2020). Em outro estudo realizado com pacientes do Reino Unido foi identificado que o alelo e4e4 do gene ApoE aumenta os riscos de infecção COVID-19 grave, independente de demência preexistente, doença cardiovascular e diabetes tipo 2. O alelo e4e4 não só afeta a função da lipoproteína mas também modera os fenótipos pró/anti-inflamatórios de macrófagos (Kuo et al., 2020).

Analisando 332 pacientes de COVID-19 categorizados por vários níveis de gravidade foi observado um efeito monogênico potencial de variantes de perda de função nos genes GOLGA3 e DPP7 para demonstração de doença grave e assintomática. O estudo de associação de todo o genoma sugere que o lócus do gene mais significativo associado à gravidade estava localizado no TMEM189-UBE2V1 que estava envolvido na via de sinalização da IL-1. A variante missense p.Val197Met que afeta a estabilidade da proteína TMPRSS2 exibe uma frequência de alelo decrescente entre os pacientes graves em comparação com a população leve e em geral (Wang et al., 2020). 
Klaassen et al., 2020, estudando 143 indivíduos da população da Sérvia, identificaram 4 variantes em genes que codificam proteases (FURIN, PLG e PRSS1) e 6 em genes envolvidos na imunidade inata (MBL2 e OASI) que podem ser relevantes para a resposta do hospedeiro à infecção por SARS-CoV-2. Estas variantes de alteração de proteína (p.Gly146Ser em FURIN; p.Arg261His e p.Ala494Val em PLG; p.Asn54Lys em PRSS1; p.Arg52Cys, p.Gly54Asp e p.Gly57Glu em MBL2; p.Arg47Gln, p.Ile99 p.Arg130His em OAS1) podem ter valor preditivo para diferenças interindividuais na resposta à infecção por SARS-CoV-2 (Klaassen et al., 2020).

Uma análise interpopulacional mostrou que a distribuição dos alelos de risco entre os europeus difere substancialmente dos africanos e da população do leste asiático. A análise dos genomas do Catar revelou que variantes de risco ligadas à gravidade do SARS-CoV-1 (CCL2, MBL, CCL5, AHSG e IL4) eram menos frequentes em comparação com o genoma a população do leste asiático (alteração de até 25 vezes). Por outro lado, SNPs em TMPRSS2, IFN- $\gamma$, ICAM3 e FURIN foram mais comuns entre a população do Catar (alteração média de 2 vezes). Dessa forma os africanos parecem carregar frequências extremamente baixas de alelos de suscetibilidade ao SARS-CoV-1, chegando a uma redução de 32 vezes em comparação com outras populações. Múltiplas variantes genéticas, que poderiam modular a infecção por SARS-CoV-2, são significativamente variáveis entre as populações, com a menor frequência observada entre africanos (Smatti et al., 2020).

Outro estudo realizado com afro-americanos foi observado que a frequência do alelo menor T no gene IFIH1 varia amplamente de africanos $(0,06$ a 0,35$)$ a chineses $(0,19$ a 0,23$)$ a caucasianos $(0,56$ a 0,69$)$. Durante os primeiros dias de infecção, a taxa de infecção na Itália foi menor do que na China. A taxa de infecção nos EUA e na Espanha foi intermediária entre esses dois países, talvez devido a uma população africana mais mista nesses países. Essas análises sugerem que afroamericanos e chineses com a menor frequência do alelo menor T de rs1990760 são mais vulneráveis à infecção por SARSCOV-2, além de outros fatores genéticos ou condições socioeconômicas nessa população (Maiti et al., 2020).

Outros genes como o CXCL1 e o CCL2O também apresentam um papel importante nas diferenças na suscetibilidade do COVID-19 entre homens e mulheres, visto que estão associados com os receptores de andrógenos. Além destes, há também o gene CXCL2 que está associado com os receptores de estrogênio que atuam majoritariamente na resposta antiviral. Todos os genes citados anteriormente sofrem modificações devido ao contato com o SARS-CoV-2 (Abdelzaher $e t$ al., 2020).

\section{Diferenças de Suscetibilidade a COVID-19 entre Homens e Mulheres}

Dados epidemiológicos tanto da Síndrome Respiratória Aguda Grave do Coronavírus (SARS), quanto do Coronavírus da Síndrome Respiratória do Oriente Médio (MERS) demonstraram que o gênero dos indivíduos é uma característica importante para o desenvolvimento do SARS-CoV-2 na população (Agrawal et al., 2020). De acordo com a literatura, indivíduos do sexo masculino apresentam uma maior taxa de mortalidade e de gravidade no quadro clínico para a COVID-19 (Agrawal et al., 2020; Alshahawey, Raslan \& Sabri, 2020; Abdelzaher et al., 2020; Haitao et al., 2020) e também para outros tipos de infecções virais agudas quando comparados com o sexo oposto (Agrawal et al., 2020).

Segundo um estudo publicado recentemente com 239.709 pacientes residentes na Itália, tanto o índice de mortalidade quanto o de letalidade foram maiores nos homens, sendo respectivamente de 59\% e 17,7\%. Enquanto nas mulheres italianas a letalidade foi de apenas 10,8\%. Entretanto, nesse mesmo estudo, os homens apresentaram uma taxa de infecção menor de apenas 45,8\% quando comparado aos 54,2\% das mulheres participantes dessa análise (Foresta, Rocca \& Di Nisio, 2020). Já em um estudo realizado na China envolvendo 140 pacientes demonstrou que a distribuição da COVID-19 ocorreu da mesma maneira para ambos os sexos, porém o quadro clínico mais grave era composto majoritariamente por homens (Zhang et al., 2020). Outro relatório chinês que envolveu a participação de 552 hospitais, relatou que a maioria dos pacientes internados acometidos por essa doença também eram do sexo masculino (Guan et al., 2020). Por fim, em um estudo com mais de 1.000 
chineses, foi relatado que a taxa de mortalidade dos homens é mais de duas vezes maior que das mulheres que apresentam o quadro mais grave da doença (Abdelzaher et al., 2020).

Essa prevalência de infecções virais nos homens pode ser explicada através das diferenças existentes entre ambos os gêneros em relação ao dimorfismo sexual, fatores genéticos, hormonais (Bienvenu et al., 2020; Haitao et al., 2020), comportamentais, sociais, a idade, gravidez (Haitao et al., 2020), menopausa (Abdelzaher et al., 2020; Haitao et al., 2020) e as diferenças das respostas imunológicas (Bienvenu et al., 2020).

A prevalência da propagação (Zhao et al., 2020) e da gravidade do COVID-19 nos indivíduos do sexo masculino também foi associada a polimorfismos presentes no gene ACE2 (Ovsyannikova et al., 2020) não só por se tratar de um receptor que apresenta uma expressão mais significativa nos homens do que nas mulheres (Ovsyannikova et al., 2020; Zhao et al., 2020), mas também por demonstrar uma diferença na regulação epigenética de $A C E 2$, no qual as mulheres apresentam um padrão de metilação do DNA relativamente menor quando comparadas ao sexo oposto (Pereira et al., 2020).

Além disso, por esse gene está localizado no cromossomo X, foi elaborado uma hipótese de suscetibilidade genética baseada no gênero, sendo os homens hemizigóticos os mais susceptíveis para infecção do SARS-CoV-2 por apresentarem e expressarem uma única variante de risco presente no gene ACE2 (Alshahawey, Raslan \& Sabri, 2020; Ovsyannikova et al., 2020). Contudo, o alto nível de expressão desse gene em mulheres pode ocorrer devido a vários fatores, dentre eles estão a presença de estrogênios e a inativação do cromossomo X (Foresta, Rocca \& Di Nisio, 2020).

\section{Discussão}

No atual cenário, é evidente que existe ainda uma taxa de mortalidade notavelmente alta de COVID-19 entre os idosos e as pessoas que possuem doenças crônicas (Mitra et al., 2020). Indivíduos com histórico de doenças crônicas, estão entre as mais suscetíveis a desenvolver formas mais graves de COVID-19, visto que há maiores chances de comprometimento da resposta imune, facilitando a replicação viral em maior escala. Assim como os idosos em que a progressão e agressividade da doença está diretamente ligado a deficiências no sistema imunológico, permitindo a intensa atuação do SARS-CoV-2 (das Merces et al., 2020).

As particularidades relacionadas a diferentes subtipos do coronavírus podem ser esclarecidas por meio das diferenças genéticas nas populações (Vargas-Alarcón, Posadas-Sánchez \& Ramírez-Bello, 2020). A partir disso, pode-se considerar que alguns grupos estão mais suscetíveis geneticamente a serem contaminados e/ou mais expostos a gravidade dessa doença (Abdelzaher et al., 2020; Benetti et al., 2020; LoPresti et al., 2020) por meio das diferenças na patogenicidade de cada pessoa infectada pelo SARS-CoV-2 (Chakravarty et al., 2020).

Devido a heterogeneidade da suscetibilidade e gravidade a doença é de fundamental importância estudos relacionados aos fatores de riscos genéticos para a suscetibilidade, às diferenças genéticas existentes em diferentes populações (Alshahawey, Raslan \& Sabri, 2020), aos fatores genéticos do hospedeiro (Choudhary et al., 2020; Debnath, Banerjee \& Berk, 2020; Murray et al., 2020), além da expressão de genes que agem como facilitadores da entrada do SARS-CoV-2, e até mesmo da resistência do indivíduo a essa doença (Godri Pollitt et al., 2020; Gutierrez, Beckford \& Alachkar, 2020; Mohammadpour et al., 2020; Murray et al., 2020).

Dessa forma, adquirir conhecimentos sobre esses mecanismos contribuem de forma significativa para o combate dessa doença em inúmeros aspectos, como por exemplo, no desenvolvimento de medidas terapêuticas (Carter-Timofte $e t$ al., 2020; Wei et al., 2020), preventivas (Carter-Timofte et al., 2020) e profilaxias mais específicas a partir do quadro clínico dos pacientes (Carter-Timofte et al., 2020; Wei et al., 2020). Além disso, faz-se necessário colaborar para uma identificação mais 
precisa no que se refere aos genes de risco e protetores e aos indivíduos que são considerados grupo de risco para a suscetibilidade do COVID-19 (Debnath, Banerjee \& Berk, 2020; COVID-19 Host Genetics Initiative, 2020).

Recentemente, constatou-se que tanto a Protease Serina Transmembrana tipo 2 (TMPRSS2) quanto a Enzima de Conversão da Angiotensina 2 (ACE2), estão sendo decisivos para a penetração do vírus nas células hospedeiras, onde, ACE2 é tido como principal receptor para o pico da proteína $(\mathrm{S})$, através do qual o vírus pode se ligar às células-alvo, ao passo que o TMPRSS2 fragmenta a proteína (S), possibilitando a fusão adicional do vírus e da membrana celular (Alshahawey, Raslan \& Sabri, 2020). De acordo com Gemmati (2020), o SARS-CoV-2 tem elevada interação com o receptor ACE2 humano, o qual realiza um papel essencial na entrada da célula juntamente com a serina protease 2 transmembrana (TMPRSS2). Atualmente, observa-se que polimorfismos de nucleotídeo único (SNPs) dos genes ACE2 e de TMPRSS2, podem definir um espectro multifatorial complexo de virulência de SARS-CoV-2 entre os acometidos com a doença, prevendo a suscetibilidade ao COVID-19 (Chiappelli, 2020).

Sabe-se que os determinantes da diferente suscetibilidade ao SARS-CoV-2 envolvem principalmente genes relacionados aos estágios iniciais da infecção (Anastassopoulou, et al., 2020). De acordo com o que foi exposto, o sistema da angiotensina $A C E 1$ e $A C E 2$ apresentou um papel importante na patogênese da COVID-19. Polimorfismos funcionais dos genes ACE1/ACE2 têm sido associados ao risco de doenças cardiovasculares e pulmonares e, portanto, também podem contribuir para o desfecho de COVID-19 (Gómez et al., 2020). A expressão global de ACE2 se mostrou significativamente maior em pacientes com diabetes, hipertensão e doença pulmonar obstrutiva crônica do que nos pulmões de pacientes saudáveis (Pinto et al., 2020). Isso pode explicar por que esses indivíduos estão predispostos a uma maior gravidade da COVID - 19 (Pathak et al., 2020). Além disso, as variações no gene ACE2 podem tornar mais fácil ou mais difícil para o SARS-CoV-2 invadir as células (Zhang et al., 2020), por isso os níveis de expressão celular de ACE2 diferem entre os indivíduos (Choudhary et al., 2020).

Existe também uma diferença racial bem estabelecida de polimorfismos do gene $A C E$, no qual os afro-americanos parecem ter uma taxa de mortalidade desproporcionalmente alta dos Estados Unidos. Da mesma forma, europeus também apresentam alta taxa de letalidade. Por outro lado, populações asiáticas parecem estar associadas a uma mortalidade relativamente baixa de COVID-19 nessas nações (Zheng \& Cao, 2020). Além disso, compreender os genes que interagem com o receptor ACE2 tem potencial para compreender alvos de drogas e processos moleculares que podem desempenhar um papel na susceptibilidade e resposta ao tratamento de COVID-19 (Pathak et al., 2020).

O gene TMPRSS2 apresenta um papel crucial na alta taxa de mortalidade dos homens infectados pelo SARS-CoV-2 (Abdelzaher et al., 2020). Tal gene está relacionado com a entrada do vírus do COVID-19 nas células hospedeiras por possibilitar a clivagem do receptor SARS-CoV-2 e a ativação dessa proteína (Choudhary et al., 2020). Segundo dados epidemiológicos, variantes genéticas desse gene contribuem de maneira significativa para a suscetibilidade dessa doença, podendo ser classificado como caráter de risco ou de proteção (Choudhary et al., 2020). Além disso, observa-se que há uma diferença nas frequências dos alelos entre as populações (Al-Eitan \& Alahmad, 2020). Foi descoberto quatros SNPs no gene TMPRSS2 (rs77675406, rs112657409, rs713400 e rs11910678) que são importantes para que ocorra o processo de infecção desse vírus nos indivíduos (Al-Eitan \& Alahmad, 2020).

O sistema de antígeno Leucocitário Humano (HLA), se mostrou ser crucial na influência de susceptibilidade e gravidade do COVID-19 (Debnath, Banerjee \& Berk, 2020), além de ser um dos sistemas mais polimórficos (Mohammadpour et al., 2020). As diferenças genéticas nos genes HLA são bem conhecidas por influenciar as variações individuais na resposta imune aos patógenos (Gutierrez, Beckford \& Alachkar, 2020) Ademais, foi descoberto que o estado de vacinação com BCG está significativamente associado às taxas de mortalidade, bem como ao número de casos infectados. A partir disso, supõe-se que os genótipos HLA bem como o estado de vacinação com BCG podem afetar a suscetibilidade à infecção pelo SARS-CoV2 ou a gravidade do COVID-19 (Toyoshima et al., 2020). 
Existem outros genes que também parecem ser associados à suscetibilidade ao SARS-CoV-2. Em uma revisão sistemática foi identificado vinte e nove polimorfismos localizados em 21 genes como associados à suscetibilidade ou resistência ao SARS-CoV e a gravidade da doença em populações asiáticas. Tais polimorfismos podem ser relevantes para a resposta do hospedeiro à infecção por SARS-CoV-2 (Ramos-Lopez et al., 2020; Klaassen et al., 2020).

Os indivíduos do sexo masculino apresentam uma maior suscetibilidade a infecção do SARS-CoV-2 (Agrawal et al., 2020) mortalidade e gravidade da doença (Agrawal et al., 2020; Alshahawey, Raslan \& Sabri, 2020; Abdelzaher $e t$ al., 2020; Haitao et al., 2020). Os principais genes que contribuem para essa peculiaridade da COVID-19 entre os gêneros são ACE1, ACE2 (Gómez et al., 2020), TMPRSS2, CXCL1, CXCL12 e CCL20 (Abdelzaher et al., 2020), visto que eles podem contribuir para uma maior ou menor predisposição genética de acordo com o grau de expressão. Portanto, foi observado que para uma melhor compreensão dos mecanismos envolvendo o SARS-CoV-2 será necessário a realização de mais estudos direcionados para essa temática de sexo biológico. Desse modo, será possível elaborar medidas de prevenção e terapêuticas mais eficazes contra a COVID-19 (Bienvenu et al., 2020).

À medida que os fatores genéticos do hospedeiro são descobertos, novas estratégias de apoio à implementação clínica devem ser testadas no intuito de melhorar os resultados de pacientes infectados com SARS-CoV-2 (Murray et al., 2020). No geral, estima-se que as ferramentas de medicina personalizada no COVID-19 serão geradas e se tornarão cada vez mais eficientes e precisas, permitindo uma melhor compreensão da heterogeneidade da infecção e da dinâmica da doença e facilitando o desenvolvimento e a implementação clínica adaptados ao perfil molecular e às necessidades específicas de cada paciente (Ragia \& Manolopoulos, 2020).

\section{Conclusão}

Esses achados sugerem que a suscetibilidade genética pode contribuir para a variabilidade clínica interindividual associada ao COVID-19. Isso permite uma avaliação de risco baseada em evidências levando a medidas preventivas personalizadas e opções terapêuticas. Além disso, a avaliação do papel das variantes genéticas na determinação das infecções respiratórias ajudará a identificar potenciais candidatos a medicamentos para estudos em pacientes com COVID-19 e na identificação de populações de alto risco que também poderiam ser priorizadas para a vacinação. Por se tratar de um tema altamente relevante, ainda há a necessidade de mais estudos que investiguem a influência da suscetibilidade na incidência e mortalidade de COVID-19. Com este trabalho, esperamos auxiliar no conhecimento atual sobre o papel potencial da genética do hospedeiro, além de ajudar a orientar a pesquisa genética e genômica atual, incentivando investigações mais aprofundadas em estudos maiores.

\section{Referências}

Agrawal, H., Das, N., Nathani, S., Saha, S., Saini, S., Kakar, S. S., \& Roy, P. (2020). An assessment on impact of COVID-19 infection in a gender specific manner. Stem cell reviews and reports, 1-19.

Al-Eitan, L. N., \& Alahmad, S. Z. (2020). Pharmacogenomics of genetic polymorphism within the genes responsible for SARS-CoV-2 susceptibility and the drug-metabolising genes used in treatment. Reviews in medical virology, e2194.

Alshahawey, M., Raslan, M., \& Sabri, N. (2020). Sex-mediated effects of ACE2 and TMPRSS2 on the incidence and severity of COVID-19; The need for genetic implementation. Current Research in Translational Medicine.

Anastassopoulou, C., Gkizarioti, Z., Patrinos, G. P., \& Tsakris, A. (2020). Human genetic factors associated with susceptibility to SARS-CoV-2 infection and COVID-19 disease severity. Human genomics, 14(1), 1-8.

Abdelzaher, H., Saleh, B. M., Ismail, H. A., Hafiz, M., Abou Gabal, M., Mahmoud, M., \& Abdelnaser, A. (2020). COVID-19 genetic and environmental risk factors: a look at the evidence. Frontiers in pharmacology, 11.

Barash, A., Machluf, Y., Ariel, I., \& Dekel, Y. (2020). The pursuit of COVID-19 biomarkers: putting the spotlight on ACE2 and TMPRSS2 regulatory sequences. Frontiers in medicine, 7. 
Benetti, E., Tita, R., Spiga, O., Ciolfi, A., Birolo, G., \& Bruselles, A. ACE2 gene variants may underlie interindividual variability and susceptibility to COVID-19 in the Italian population. medRxiv. 2020: 2020.04. 03.20047977.

Bienvenu, L. A., Noonan, J., Wang, X., \& Peter, K. (2020). Higher mortality of COVID-19 in males: sex differences in immune response and cardiovascular comorbidities. Cardiovascular Research, 116(14), 2197-2206.

Chakravarty, S. (2020). COVID-19: The Effect of Host Genetic Variations on Host-Virus Interactions. Journal of Proteome Research.

Cammarata-Scalisi, F., Tadich, A. C., \& Callea, M. (2020). Genetic variability in the case of COVID-19 infection. Archivos Argentinos de Pediatria, 118(5).

Chiappelli, F. (2020). CoViD-19 Susceptibility. Bioinformation, 16(7), 501.

Carter-Timofte, M. E., Jørgensen, S. E., Freytag, M. R., Thomsen, M. M., Andersen, N. S. B., Al-Mousawi, A., \& Mogensen, T. H. (2020). Deciphering the role of host genetics in susceptibility to severe COVID-19. Frontiers in Immunology, 11.

COVID-19 Host Genetics Initiative. (2020). The COVID-19 Host Genetics Initiative, a global initiative to elucidate the role of host genetic factors in susceptibility and severity of the SARS-CoV-2 virus pandemic. European Journal of Human Genetics, 1.

Choudhary, S., Sreenivasulu, K., Mitra, P., Misra, S., \& Sharma, P. Role of genetic variants and gene expression in the susceptibility and severity of COVID19. Ann Lab Med, 2021(41), 129-38.

Chen, L., \& Zheng, S. (2020). Understand variability of COVID-19 through population and tissue variations in expression of SARS-CoV-2 host genes. Informatics in medicine unlocked, 21, 100443.

das Mercês, D. M., da Silva Abdias, G., Moreira, T. A., Lima, F. L. O., \& de Vasconcellos Neto, J. R. T. (2020). Doença de coronavírus 2019 (covid-19): mecanismos, diagnóstico diferencial e influência das medidas de intervenção. Research, Society and Development, 9(8), e921986075-e921986075.

Debnath, M., Banerjee, M., \& Berk, M. (2020). Genetic gateways to COVID-19 infection: Implications for risk, severity, and outcomes. The FASEB Journal.

de Figueiredo, M. C. F., do Nascimento, J. M. F., Araújo, D. S., Silva, T. R., Barros, F. D. D., de Moura, F. V. P., \& Pereira-Freire, J. A. (2020). O impacto do excesso de peso nas complicações clínicas causadas pela COVID-19: Uma revisão sistemática. Research, Society and Development, 9(7), e693974791e693974791.

Dobrindt, K., Hoagland, D. A., Seah, C., Kassim, B., O'Shea, C. P., Iskhakova, M., \& Murphy, A. (2020). Common genetic variation in humans impacts in vitro susceptibility to SARS-CoV-2 infection. bioRxiv.

Devaux, C. A., Rolain, J. M., \& Raoult, D. (2020). ACE2 receptor polymorphism: Susceptibility to SARS-CoV-2, hypertension, multi-organ failure, and COVID-19 disease outcome. Journal of Microbiology, Immunology and Infection.

Elhabyan, A., El Yaacoub, S., Sanad, E., Mohamed, A., Elhabyan, A., \& Dinu, V. (2020). The role of host genetics in susceptibility to severe viral infections in humans and insights into host genetics of severe COVID-19: A systematic review. Virus Research, 198163.

Fujikura, K., \& Uesaka, K. (2020). Genetic variations in the human severe acute respiratory syndrome coronavirus receptor ACE2 and serine protease TMPRSS2. Journal of Clinical Pathology.

Foresta, C., Rocca, M. S., \& Di Nisio, A. (2020). Gender susceptibility to COVID-19: a review of the putative role of sex hormones and X chromosome. Journal of Endocrinological Investigation, 1-6.

Godri Pollitt, K. J., Peccia, J., Ko, A. I., Kaminski, N., Dela Cruz, C. S., Nebert, D. W., \& Vasiliou, V. (2020). COVID-19 vulnerability: the potential impact of genetic susceptibility and airborne transmission. Human Genomics, 14, 1-7.

Gemmati, D., Bramanti, B., Serino, M. L., Secchiero, P., Zauli, G., \& Tisato, V. (2020). COVID-19 and Individual Genetic Susceptibility/Receptivity: Role of ACE1/ACE2 Genes, Immunity, Inflammation and Coagulation. Might the Double X-Chromosome in Females Be Protective against SARS-CoV-2 Compared to the Single X-Chromosome in Males?. International Journal of Molecular Sciences, 21(10), 3474.

Gómez, J., Albaiceta, G. M., García-Clemente, M., López-Larrea, C., Amado-Rodríguez, L., Lopez-Alonso, I., \& Alvarez-Argüelles, M. E. (2020). Angiotensin-converting enzymes (ACE, ACE2) gene variants and COVID-19 outcome. Gene, 762, 145102.

Guan, W. J., Ni, Z. Y., Hu, Y., Liang, W. H., Ou, C. Q., He, J. X., \& Du, B. (2020). Clinical characteristics of coronavirus disease 2019 in China. New England journal of medicine, 382(18), 1708-1720.

Gutierrez, L., Beckford, J., \& Alachkar, H. (2020). Deciphering the TCR repertoire to solve the COVID-19 mystery. Trends in Pharmacological Sciences.

Haitao, T., Vermunt, J., Abeykoon, J., Ghamrawi, R., Gunaratne, M., Jayachandran, M., \& Garovic, V. (2020, August). COVID-19 and sex differences: mechanisms and biomarkers. In Mayo Clinic Proceedings. Elsevier.

Hou, Y., Zhao, J., Martin, W., Kallianpur, A., Chung, M. K., Jehi, L., \& Cheng, F. (2020). New insights into genetic susceptibility of COVID-19: an ACE2 and TMPRSS2 polymorphism analysis. BMC medicine, 18(1), 1-8.

Hussain, M., Jabeen, N., Raza, F., Shabbir, S., Baig, A. A., Amanullah, A., \& Aziz, B. (2020). Structural variations in human ACE2 may influence its binding with SARS-CoV-2 spike protein. Journal of medical virology.

Korber, B., Fischer, W. M., Gnanakaran, S., Yoon, H., Theiler, J., Abfalterer, W., \& Hastie, K. M. (2020). Tracking changes in SARS-CoV-2 Spike: evidence that D614G increases infectivity of the COVID-19 virus. Cell, 182(4), 812-827. 
Kuo, C. L., Pilling, L. C., Atkins, J. L., Masoli, J. A., Delgado, J., Kuchel, G. A., \& Melzer, D. (2020). APOE e4 genotype predicts severe COVID-19 in the UK Biobank community cohort. medRxiv.

Kachuri, L., Francis, S. S., Morrison, M., Bossé, Y., Cavazos, T. B., Rashkin, S. R., \& Witte, J. S. (2020). The landscape of host genetic factors involved in infection to common viruses and SARS-CoV-2. medRxiv.

Klaassen, K., Stankovic, B., Zukic, B., Kotur, N., Gasic, V., Pavlovic, S., \& Stojiljkovic, M. (2020). Functional prediction and comparative population analysis of variants in genes for proteases and innate immunity related to SARS-CoV-2 infection. bioRxiv.

Latini, A., Agolini, E., Novelli, A., Borgiani, P., Giannini, R., Gravina, P., \& Novelli, G. (2020). COVID-19 and genetic variants of protein involved in the SARS-CoV-2 entry into the host cells. Genes, 11(9), 1010.

Lorente, L., Martín, M. M., Franco, A., Barrios, Y., Cáceres, J. J., Solé-Violán, J., \& Jiménez, A. (2020). HLA genetic polymorphisms and prognosis of patients with COVID-19. Medicina intensiva.

LoPresti, M., Beck, D. B., Duggal, P., Cummings, D. A., \& Solomon, B. D. (2020). The Role of Host Genetic Factors in Coronavirus Susceptibility: Review of Animal and Systematic Review of Human Literature. medRxiv.

Lacoma, A., Mateo, L., Blanco, I., Méndez, M. J., Rodrigo, C., Latorre, I., ... \& Prat, C. (2019). Impact of host genetics and biological response modifiers on respiratory tract infections. Frontiers in immunology, 10, 1013.

Li, Q., Guan, X., Wu, P., Wang, X., Zhou, L., Tong, Y., \& Xing, X. (2020). Early transmission dynamics in Wuhan, China, of novel coronavirus-infected pneumonia. New England Journal of Medicine.

Lingeswaran, M., Goyal, T., Ghosh, R., Suri, S., Mitra, P., Misra, S., \& Sharma, P. (2020). Inflammation, Immunity and Immunogenetics in COVID-19: A Narrative Review. Indian Journal of Clinical Biochemistry, 1.

Liu, D., Yang, J., Feng, B., Lu, W., Zhao, C., \& Li, L. (2020). Mendelian randomization analysis identified genes pleiotropically associated with the risk and prognosis of COVID-19. Journal of Infection.

Mitra, P., Suri, S., Goyal, T., Misra, R., Singh, K., Garg, M. K., \& Sharma, P. (2020). Association of comorbidities with Coronavirus disease 2019: A review. Annals of the National Academy of Medical Sciences (India).

Murray, M. F., Kenny, E. E., Ritchie, M. D., Rader, D. J., Bale, A. E., Giovanni, M. A., \& Abul-Husn, N. S. (2020). COVID-19 outcomes and the human genome. Genetics in Medicine, 1-3.

Mohammadpour, S., Torshizi Esfahani, A., Halaji, M., Lak, M., \& Ranjbar, R. (2020). An updated review of the association of host genetic factors with susceptibility and resistance to COVID-19. Journal of Cellular Physiology, 236(1), 49-54.

Maiti, A. K. (2020). The African-American population with a low allele frequency of SNP rs1990760 (T allele) in IFIH1 predicts less IFN-beta expression and potential vulnerability to COVID-19 infection. Immunogenetics, 72(6), 387-391.

Moradi, F., Enjezab, B., \& Ghadiri-Anari, A. (2020). The role of androgens in COVID-19. Diabetes \& Metabolic Syndrome: Clinical Research \& Reviews.

Novelli, A., Andreani, M., Biancolella, M., Liberatoscioli, L., Passarelli, C., Colona, V. L., \& Andreoni, M. (2020). HLA allele frequencies and susceptibility to COVID-19 in a group of 99 Italian patients. Hla, 96(5), 610-614.

Nguyen, A., David, J. K., Maden, S. K., Wood, M. A., Weeder, B. R., Nellore, A., \& Thompson, R. F. (2020). Human leukocyte antigen susceptibility map for SARS-CoV-2. Journal of virology.

Khan, F. A. (2020). The role of selectivity of the SARS-CoV-2 virus for human genetic profiles in susceptibility and resistance to COVID-19. New Microbes and New Infections, 36 .

Ovsyannikova, I. G., Haralambieva, I. H., Crooke, S. N., Poland, G. A., \& Kennedy, R. B. (2020). The role of host genetics in the immune response to SARS-CoV-2 and COVID-19 susceptibility and severity. Immunological reviews, 296(1), 205-219.

Pathak, G. A., Wendt, F., Goswami, A., De Angelis, F., Polimanti, R., \& COVID-19 Host Genetics Initiative. (2020). ACE2 Netlas: In-silico functional characterization and drug-gene interactions of ACE2 gene network to understand its potential involvement in COVID-19 susceptibility. medRxiv.

Pisanti, S., Deelen, J., Gallina, A. M., Caputo, M., Citro, M., Abate, M., \& Martinelli, R. (2020). Correlation of the two most frequent HLA haplotypes in the Italian population to the differential regional incidence of Covid-19. Journal of translational medicine, 18(1), 1-16.

Panda, A. K., Padhi, A., \& Prusty, B. A. K. (2020). CCR5 $\Delta 32$ minorallele is associated with susceptibility to SARS-CoV-2 infection and death: An epidemiological investigation. Clinica Chimica Acta; International Journal of Clinical Chemistry.

Pinto, B. G., Oliveira, A. E., Singh, Y., Jimenez, L., Goncalves, A. N., Ogava, R. L., \& Nakaya, H. I. ACE2 Expression is Increased in the Lungs of Patients with Comorbidities Associated with Severe COVID-19. medRxiv. 2020.

Paniri, A., Hosseini, M. M., Eslam, M. M., \& Akhavan-Niaki, H. (2020). Comprehensive in silico identification of impacts of ACE2 SNPs on COVID-19 susceptibility in different populations. Gene reports, 100979.

Pereira, N. L., Ahmad, F., Cummins, N. W., Byku, M., Morris, A. A., Owens, A., \& Cresci, S. (2020, December). COVID-19: Understanding Inter-Individual Variability and Implications for Precision Medicine. In Mayo Clinic Proceedings. Elsevier.

Pereira, A. S., Shitsuka, D. M., Parreira, F. J., \& Shitsuka, R. (2018). Metodologia da pesquisa científica. 
Ramos-Lopez, O., Daimiel, L., Ramírez de Molina, A., Martínez-Urbistondo, D., Vargas, J. A., \& Martínez, J. A. (2020). Exploring Host Genetic Polymorphisms Involved in SARS-CoV Infection Outcomes: Implications for Personalized Medicine in COVID-19. International journal of genomics, 2020.

Ragia, G., \& Manolopoulos, V. G. (2020). Assessing COVID-19 susceptibility through analysis of the genetic and epigenetic diversity of ACE2 mediated SARS-CoV-2 entry. Pharmacogenomics, (0).

Ravaioli, S., Tebaldi, M., Fonzi, E., Angeli, D., Mazza, M., Nicolini, F., \& Bravaccini, S. (2020). ACE2 and TMPRSS2 Potential Involvement in Genetic Susceptibility to SARS-COV-2 in Cancer Patients. Cell transplantation, 29, 0963689720968749.

Renieri, A., Benetti, E., Tita, R., Spiga, O., Ciolfi, A., Birolo, G., \& Musacchia, F. (2020). ACE2 variants underlie interindividual variability and susceptibility to COVID-19 in Italian population. medRxiv.

Sharma, P., Pandey, A. K., \& Bhattacharyya, D. K. (2020). Determining crucial genes associated with COVID-19 based on COPD Findings $*$,* Computers in biology and medicine, 128, 104126.

Sakuraba, A., Haider, H., \& Sato, T. (2020). Population Difference in Allele Frequency of HLA-C* 05 and Its Correlation with COVID-19 Mortality. Viruses, 12(11), 1333 .

Samuel, R. M., Majd, H., Richter, M. N., Ghazizadeh, Z., Zekavat, S. M., Navickas, A., \& Koh, K. D. (2020). Androgen Signaling Regulates SARS-CoV-2 Receptor Levels and Is Associated with Severe COVID-19 Symptoms in Men. Cell Stem Cell, 27(6), 876-889.

Sousa, G. O., Sales, B. N., Rodrigues, A. M. X., de Moura Rocha, G. M., \& de Oliveira, G. A. L. (2020). Evolução epidemiológica da COVID-19 no Brasil e no mundo. Research, Society and Development, 9(7), e630974653-e630974653.

Srivastava, A., Bandopadhyay, A., Das, D., Pandey, R. K., Singh, V., Khanam, N., \& Gupta, P. (2020). Genetic association of ACE2 rs2285666 polymorphism with Covid-19 spatial distribution in India. Frontiers in genetics, 11, 1163.

Smatti, M. K., Al-Sarraj, Y. A., Albagha, O., \& Yassine, H. M. (2020). Host genetic variants potentially associated with SARS-CoV-2: A multi-population analysis. Frontiers in genetics, 11 .

Toyoshima, Y., Nemoto, K., Matsumoto, S., Nakamura, Y., \& Kiyotani, K. (2020). SARS-CoV-2 genomic variations associated with mortality rate of COVID-19. Journal of human genetics, 65(12), 1075-1082.

Tomita, Y., Ikeda, T., Sato, R., \& Sakagami, T. (2020). Association between HLA gene polymorphisms and mortality of COVID-19: An in silico analysis. Immunity, inflammation and disease, 8(4), 684-694.

Thomson, B. (2020). The COVID-19 pandemic: A global natural experiment. Circulation.

Vargas-Alarcón, G., Posadas-Sánchez, R., \& Ramírez-Bello, J. (2020). Variability in genes related to SARS-CoV-2 entry into host cells (ACE2, TMPRSS2, TMPRSS11A, ELANE, and CTSL) and its potential use in association studies. Life Sciences, 260, 118313.

Wang, J., Xu, X., Zhou, X., Chen, P., Liang, H., Li, X., \& Hao, P. (2020). Molecular simulation of SARS-CoV-2 spike protein binding to pangolin ACE2 or human ACE2 natural variants reveals altered susceptibility to infection. The Journal of general virology, 101(9), 921.

Wei, J., Alfajaro, M. M., DeWeirdt, P. C., Hanna, R. E., Lu-Culligan, W. J., Cai, W. L., \& Chen, J. S. (2020). Genome-wide CRISPR screens reveal host factors critical for SARS-CoV-2 infection. Cell.

Wang, F., Huang, S., Gao, H., Zhou, Y., Lai, C., Li, Z., \& Tang, Q. (2020). Initial Whole Genome Sequencing and Analysis of the Host Genetic Contribution to COVID-19 Severity and Susceptibility. medRxiv.

WHO Statement Regarding Cluster of Pneumonia Cases in Wuhan, China. Who.int. (2020). Retrieved 9 January 2020, from https://www.who.int/china/news/detail/09-01-2020-who-statement-regarding-cluster-of-pneumonia-cases-in-wuhan-china

Yamamoto, N., Ariumi, Y., Nishida, N., Yamamoto, R., Bauer, G., Gojobori, T., \& Mizokami, M. (2020). SARS-CoV-2 infections and COVID-19 mortalities strongly correlate with ACE1 I/D genotype. Gene, 758, 144944.

Zuil, D. M., Fontoura, V. M., Santos, F. S., Neto, M. S., Pascoal, L. M., Martins, M. C. N. S. E., \& Graepp-Fontoura, I. Esquemas terapêuticos para combate da Covid-19: revisão sistemática. Research, Society and Development, 10(1), e21310111533-e21310111533.

Zhang, Y. M., Wang, L., Liu, X. Z., \& Zhang, H. (2020). The COVID-19 Pandemic from a Human Genetic Perspective. Journal of proteome research, 19(11), 4374-4379.

Zheng, H., \& Cao, J. J. (2020). ACE gene polymorphism and severe lung injury in patients with COVID-19. The American journal of pathology.

Zhao, Y., Zhao, Z., Wang, Y., Zhou, Y., Ma, Y., \& Zuo, W. (2020). Single-cell RNA expression profiling of ACE2, thereceptor of SARS-CoV-2. Biorxiv.

Zhang, W., Zhao, Y., Zhang, F., Wang, Q., Li, T., Liu, Z., \& Zeng, X. (2020). The use of anti-inflammatory drugs in the treatment of people with severe coronavirus disease 2019 (COVID-19): The experience of clinical immunologists from China. Clinical Immunology, 108393.

Zhu, Z., Hasegawa, K., Ma, B., Fujiogi, M., Camargo Jr, C. A., \& Liang, L. (2020). Association of asthma and its genetic predisposition with the risk of severe COVID-19. Journal of Allergy and Clinical Immunology. 